\title{
STUDI KINETIKA REBUSAN DAUN SAMBUNG NYAWA DALAM MEMPERCEPAT PENURUNAN HIPERTENSI
}

\author{
Manja Azhari*1 \\ ${ }^{1}$ Pendidikan Kimia, FMIP, Universitas Negeri Padang, Indonesia \\ *E-mail: Manjaazharii255@gmail.com
}

\begin{abstract}
Abstrak. Studi ini bertujuan untuk membuat rebusan daun sambung nyawa untuk menurunkan penyakit hipertensi. Metode yang digunakan adalah eksperimen dan uji aktivitas katalitik secara langsung. Tahapan pertama dilakukan dengan pembuatan rebusan dari daun smabung nyawa. Uji aktivitas langsung dilakukan dengan variasi 3 gelas sehari untuk 7 helai daun, 2 gelas sehari untuk 5 helai daun, 1 gelas sehari untuk 3 helai daun dan 1 gelas sehari untuk 1 daun. Hasil eksperimen membuktikan bahwa rebusan daun sambung nyawa dapat menurunkan penyakit hipertensi. Kondisi optimum ekstrak tercapai pada 7 gelas selama 4 hari. Penyembuhan ini diduga karena akivitas katalitik rebusan daun sambung nyawa terhadap penyakit hipertensi.
\end{abstract}

Kata kunci: katalitik, rebusan, daun sambung nyawa, hipertensi, flavonoid, saponin, tannin

\section{PENDAHULUAN}

Reaksi kimia adalah sesuatu yang sangat penting dalam kehidupan. Adanya reaksi kimia dapat ditandai dengan perubahan suhu, perubahan warna, perubahan $\mathrm{pH}$, terjadinya endapan dll. Reaksi kimia yang terjadi ini dapat berlangsung dengan cepat dan dapat juga berlangusng dengan sangat lambat[1]. Cepat atau lambatnya suatu reaksi tergantung dari laju reaksi tersebut. Laju reaksi suatu senyawa dapat dipercepat dengan bantuan katalis[2]. Katalis adalah suatu zat yang dapat membatnu mempercepat laju reaksi tanpa mempengaruhi hasil akhir. Katalis terbagi dua yaitu katalis alami dan juga katalis sintesis[10-11]

Katalis alami banyak terdapat diberbagai jenis tumbuhan. Contoh dari katalis alami itu adalah enzim. Pada tumbuhan terdapat berbagai enzim yang dapat berperan dalam mempercepat laju reaksi[7]. Salah satu contoh tumbuhan yang dapat berperan dalam mempercepat laju reaksi adalah tanaman sambung nyawa[8-9] 
Tanaman sambung nyawa merupakan tanaman yang banyak dijumpai di berbagai daerah terutama daerah Ujung Batu kabupaten Rokan Hulu karena tumbuhan ini bisa hidup dengan bebas di alam. Hanya saja, banyak dari orang-orang yang tidak tahu bahwa tanaman sambung nyawa ini memiliki khasiat untuk obat berbagai penyakit, karena itulah tanaman ini disebut sebagai tanaman penyambung nyawa[18-19]. Salah satu penyakit yang mampu disembuhkan dengan tanaman sambung nyawa ini adalah hipertensi[3-4]

Hipertensi adalah suatu penyakit dimana tekanan darah tinggi dari keadaan yang normal. Yang mana untuk tekanan darah normal pada manusia biasanya berkisar antar 120/80 $\mathrm{mmHg}[5-6]$. Penyakit ini bisa dikatakan berbahaya, karena bisa saja menyebabkan kematian kapan saja. Berdasarkan penelitian dari berbagai pakar, dikatakan bahwa banyak dari penduduk Indonesia yang terkena penyakit hipertensi[20]. Biasanya, penyakit hipertensi ini memiliki berbagai pantangan makanan, misalnya saja makanan olahan seperti daging sapi. Dan hal ini dihindari oleh penderita hipertensi[21-22]

Selain menghindari berbagai jenis pantangan makanan, penyakit hipertensi ini biasanya diobati dengan obat-obat kimia pada umumnya[23-25]. Sedangkan kita tahu, bahwa obat-obat kimia ini memiliki efek samping[26-28]. Padahal tanpa kita sadari, penyakit hipertensi ini bisa saja kita obati dengan penggunaan obat alami seperti penggunaan tanaman sambung nyawa[32]. Berdasarkan permasalahan diatas, maka penulis membuat paper ini dengan tujuan untuk bisa mengetahui manfaat dari ekstrak tanaman sambung nyawa yang bisa menurunkan penyakit hipertensi[15-16]

\section{METODE}

\section{Alat dan bahan}


Alat yang digunakan dalam pembuatan rebusan daun sambung nyawa ini adalah mangkuk dengan merk Tupperware, gelas dengan merk royalex, panci dengan merk cosmos, sendok dengan merk oxone, saringan dengan merk pigeon dan kompor dengan merk rinai.

Untuk bahan pembuatan rebusan ini adalah daun sambung nyawa yang diambil dari daerah ujung batu kabupaten rokan hulu, dan juga air gallon yang dibeli di fariz water yang ada dijalan tanah datar, kecamatan ujung batu.

\section{Penyiapan sampel}

Sampel berupa daun sambung nyawa yang diambil dari daerah ujungbatu, jalan tanah datar, kecamatan ujung batu, kabupaten rokan hulu.

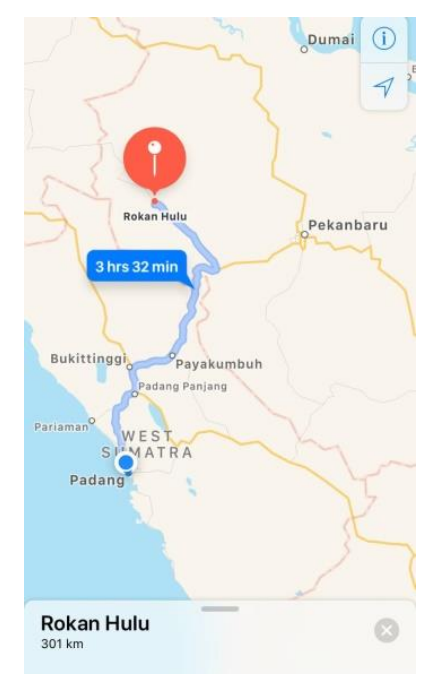

Gambar 1. Lokasi tanaman sambung nyawa 


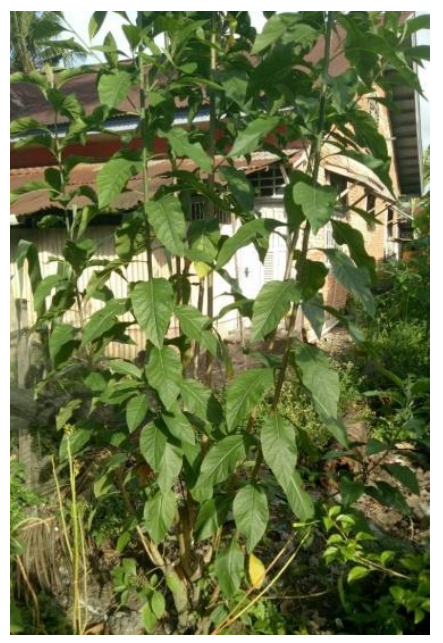

Gambar 2. Tanaman sambung nyawa

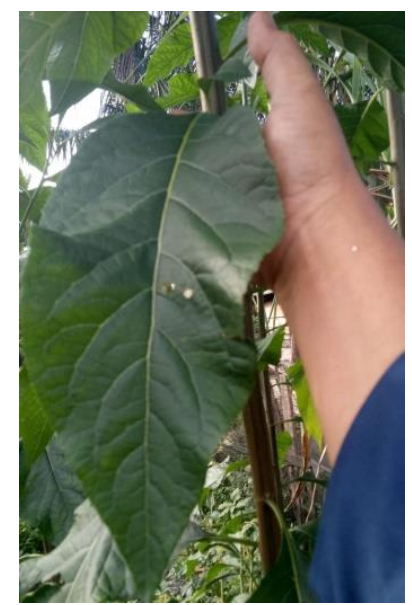

Gambar 3. Daun sambung nyawa

Untuk membuat rebusan tanaman sambung nyawa, daun diambil sebanyak 7 helai untuk hari pertama, 5 helai untuk hari kedua, 3 helai untuk hari ketiga dan 1 helai untuk hari keempat. Kemudian daun tersebut dimasukkan ke dalam mangkuk untuk melakukan pencucian supaya kotoran atau debu yang mungkin ada di daun tersebut bisa hilang. Setelah daun dicuci, daun sambung nyawa tersebut dimasukkan ke dalam panci yang bermerk cosmos untuk merebus daun sambung nyawa. Daun sambung nyawa direbus dengan air gallon yang bermerk fariz water sebanyak 1 liter. Daun yang sudah direbus lalu disaring dengan penyaring yang bermerk pigeon kemudian dimasukkan ke dalam gelas 
yang bermerk royalex. Hasil rebusan daun sambung nyawa pada hari pertama yaitu 7 helai, menghasilkan sebanyak 3 gelas air rebusan.

\section{Pengujian ekstrak}

Ekstrak yang sudah selesai direbus, dicobakan pada salah seorang wanita yang terkena penyakit hipertensi yang ada diujung batu dengan variasi pada hari pertama sebanyak 3 gelas air rebusan daun sambung nyawa yang diminum saat pagi, siang dan malam. Dan untuk hari kedua, sebanyak 2 gelas, yaitu pagi dan malam, hari ketiga sebanyak 1 gelas di pagi hari dan hari keempat juga 1 gelas dipagi hari.

Setelah mengkonsumsi rebusan daun sambung nyawa ini secara rutin, wanita ini mengatakan bahwa tekanan darahnya yang semula $180 / 120 \mathrm{mmHg}$ mengalami penurunan menjadi 120/80 mmHg. Dan ia juga mengatakan bahwa setelah meminum rebusan daun sambung nyawa tersebut kepalanya sudah tidak sakit lagi dan kondisi badannyapun terasa lebih membaik dari sebelumnya.

Metode ini dapat dilihat pada diagram alir berikut:

7 helai daun sambung nyawa

-memasukkan daun dalam mangkuk

-mencuci daun dengan air

-mengeringkan daun

Memasukkan daun kedalam panci

-memasukkan air ke dalam panci

-merebus daun selama 20 menit

-kemudian saring air rebusan

Air rebusan dimasukkan ke dalam gelas dan siap untuk diminum 


\section{HASIL}

Hasil pembuatan ekstrak rebusan daun sambung nyawa diperoleh dari 7 helai daun dalam 1 liter air. Sehingga dihasilkan air rebusan sebanyak $900 \mathrm{ml}$ yang dibagi ke dalam 3 gelas. Hal ini dapat dilihat pada gambar dibawah

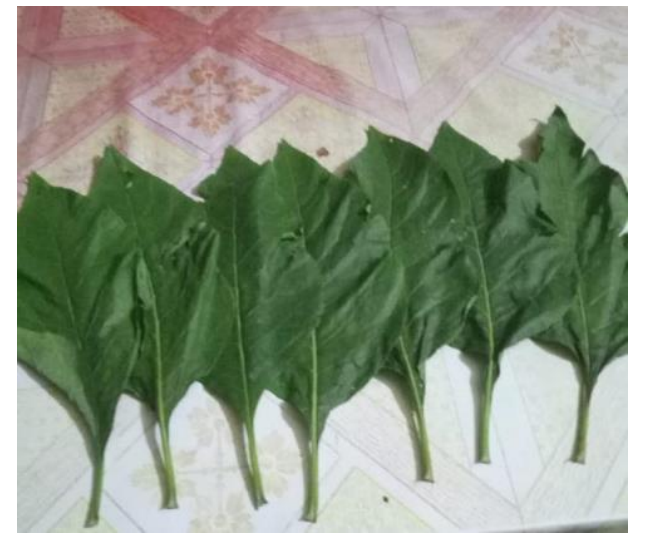

Gambar 4. 7 helai daun sambung nyawa

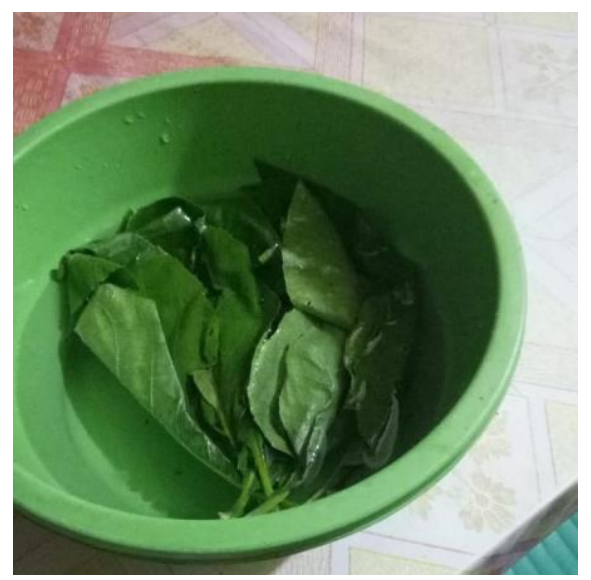

Gambar 5. Pencucian daun sambung nyawa 


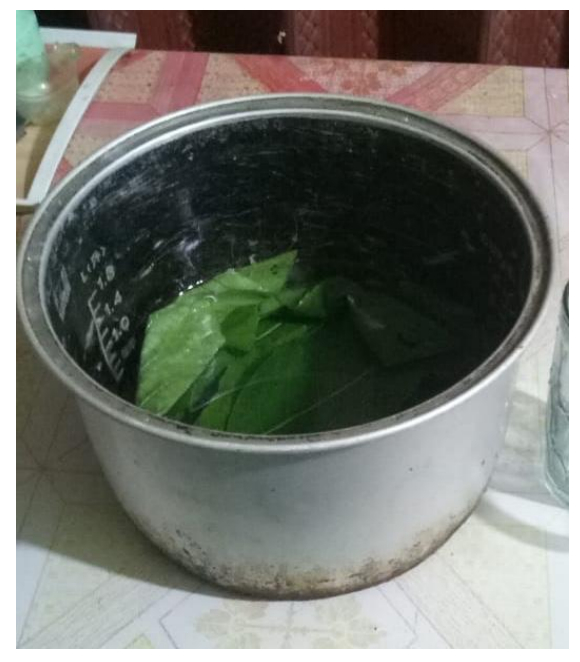

Gambar 6. Daun didalam panci

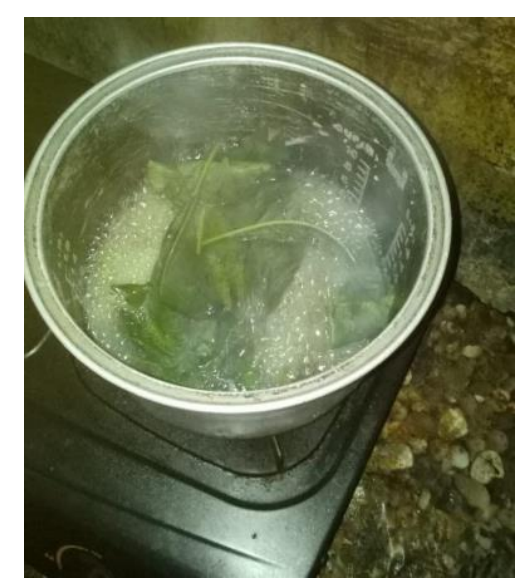

Gambar 7. Merebus daun sambung nyawa

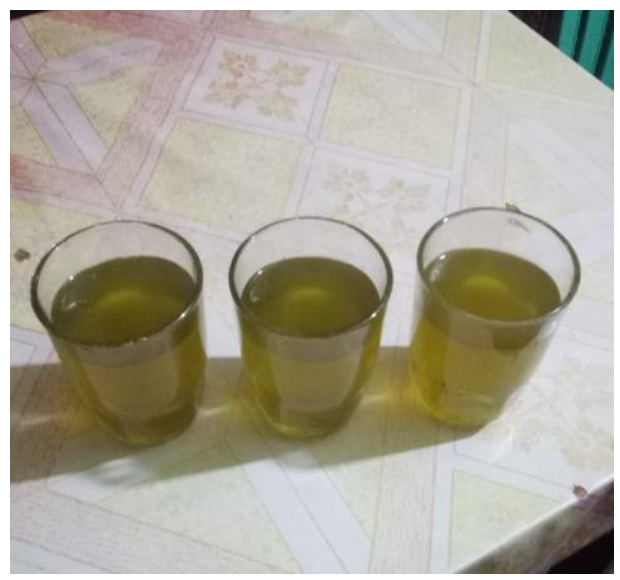

Gambar 8. Hasil rebusan daun sambung nyawa 


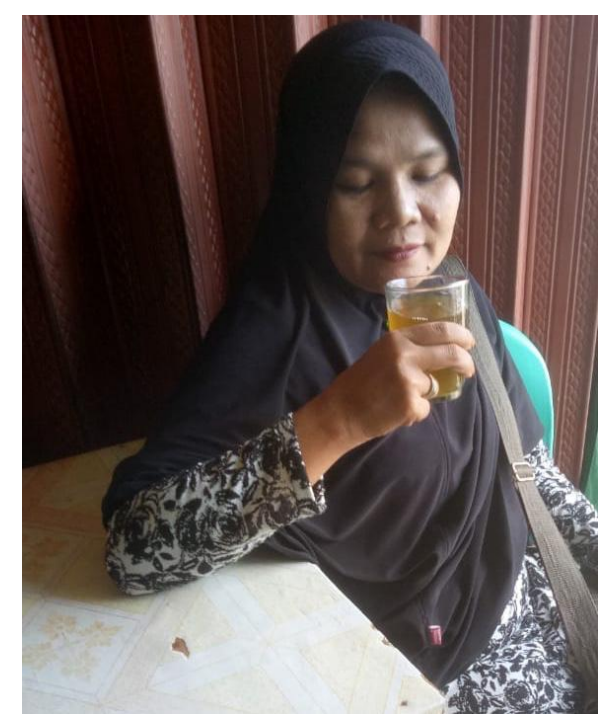

Gambar 9. Air rebusan saip diminum

Pengujian dilakukan terhadap seorang wanita yang terkena penyakit hipertensi, dan ternyata setelah mengkonsumsi rebusan daun sambung nyawa ini dapat menurunkan hipertensinya. Sebagaimana table berikut ini

Table 1. penurunan tekanan darah dari hari 1 sampai hari ke -4

\begin{tabular}{|l|l|l|l|}
\hline No. & Hari & Variasi daun & Penuruna tekanan darah \\
\hline 1 & Pertama & 7 helai & 20 \\
\hline 2 & Kedua & 5 helai & 20 \\
\hline 3 & Ketiga & 3 helai & 10 \\
\hline 4 & Keempat & 1 helai & 10 \\
\hline
\end{tabular}

\section{PEMBAHASAN}

Tanaman sambung nyawa (Gynura procumbens) merupakan salah satu tanaman yang mampu menurunkan tekanan darah tinggi. Pembuatan obat dari tanaman sambung nyawa ini juga tidak sulit, dan tidak perlu menggunakan banyak biaya. Untuk membuat ekstrak daun sambung nyawa ini kita cukup mengambil sampel daun sebanyak 16 helai untuk 4 hari pemakaian[12-14]. Yang mana untuk hari pertama kita merebus daun sambung nyawa 
sebanyak 7 helai, untuk hari kedua sebanyak 5 helai, hari ketiga sebanyak 3 helai, dan hari keempat sebanyak 1 helai. Menurut penelitian, daun sambung nyawa yang digunakan harus dalam jumlah ganjil, biasanya dimulai dari 11 helai ataupun 7 helai, supaya lebih berkhasiat dalam proses penyembuhannya[17]

Kemudian daun yang telah disediakan dimasukkan ke dalam mangkuk untuk menyiapkan proses pencucian daun, pencucian ini dilakukan untuk menghindari adanya kotoran pada daun. Untuk mencuci daun ini kita bisa menggunakan air gallon yang dibeli ditoko fariz water di daerah ujungbatu, kabupaten rokan hulu supaya lebih bersih. Setelah melakukan pencucian, selanjutnya daun dimasukkan ke dalam wadah yang lain untuk dikeringkan. Setelah daun tersebut kering, daun dimasukkan ke dalam panci bermerk cosmos yang telah diisi dengan air gallon dari fariz water sebanyak 1 liter supaya lebih baik dalam proses perebusan. Perebusan daun sambung nyawa ini bisa menggunakan kompor yang bermerk rinai, dan waktu perebusan dilakukan selama 20 menit.

Setelah daun sambung nyawa direbus, selanjutnya hasil rebusan tersebut didinginkan terlebih dahulu. Lalu setelah dingin, hasil rebusannya disaring menggunakan penyaring dan dimasukkan ke dalam gelas yang sudah disediakan sebanyak 3 gelas. Rebusan di gelas pertama diminum pada pagi hari, di gelas kedua diminum di siang hari, dan gelas ketiga diminum pada malam hari. Dan untuk hari kedua, daun sambung nyawa direbus sebanyak 5 helai, hari ketiga sebanyak 3 helai dan hari keempat sebanyak1 helai. Untuk proses pembuatannya sama seperti sebelumnya. Rebusan daun sambung nyawa ini harus dikonsumsi secara rutin supaya tekanan darah bisa kembali normal.

Setelah mengkonsumsi rebusan daun sambung nyawa secara rutin, wanita yang terkena penyakit hipertensi ini mengatakan bahwa tekanan darahnya yang semula 180/120 $\mathrm{mmHg}$ mengalami penurunan menjadi $120 / 80 \mathrm{mmHg}$ dalam 4 hari, yang mana pada hari pertama tekanan darahnya mengalami penurunan menjadi $160 / 90 \mathrm{mmHg}$, hari kedua mengalami penurunan menjadi $140 / 90 \mathrm{mmHg}$, hari ketiga menjadi $130 / 80 \mathrm{mmHg}$, dan hari keempat 
mengalami penurunan menjadi $120 / 80 \mathrm{mmHg}$ dan saat melakukan pengecekan tekanan darah, ternyata tekanan darahnya sudah kembali normal. Menurutnya, khasiat rebusan daun sambung nyawa ini sangat cepat dan terbukti bisa menurunkan tekanan darahnya. Ia juga mengatakan bahwa setelah mengkonsumsi rebusan daun ini, badannya juga terasa lebih membaik.

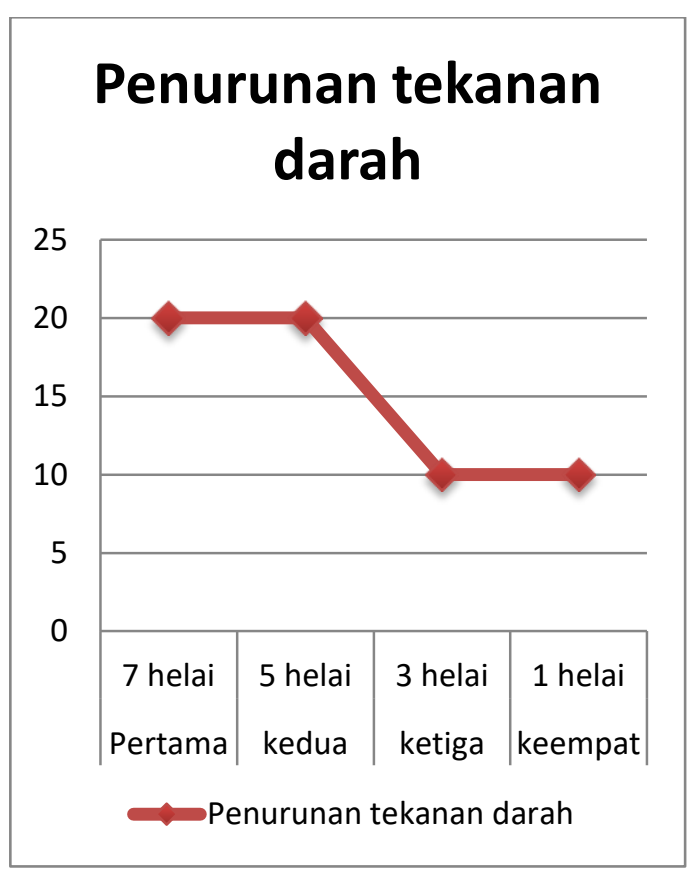

Pada kurva diatas terlihat bahwa dalam 4 hari penggunaan rebusan daun sambung nyawa penyakit hipertensi mengalami penurunan sebanyak $60 \mathrm{mmHg}$, yang mana tekanan darah wanita tersebut mulanya 180/120 $\mathrm{mmHg}$ menjadi $120 / 80 \mathrm{mmHg}$, dan kondisi tekanan darahnya kembali normal.

Tanaman sambung nyawa memang memiliki khasiat yang baik untuk menurukan hipertensi, karena menurut penelitian tanaman sambung nyawa tersebut memiliki kandungan antara lain flavonoid (glikosida kuersetin), tannin, saponin, steroid, triterpenoid, asam klorogenat, asam kafeat, asam para kumarin, dan asam para hidroki benzoat. Berikut adalah struktur kiminya[29-31] 


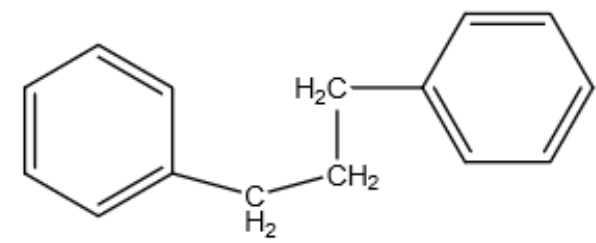

Gambar.Flavonoid

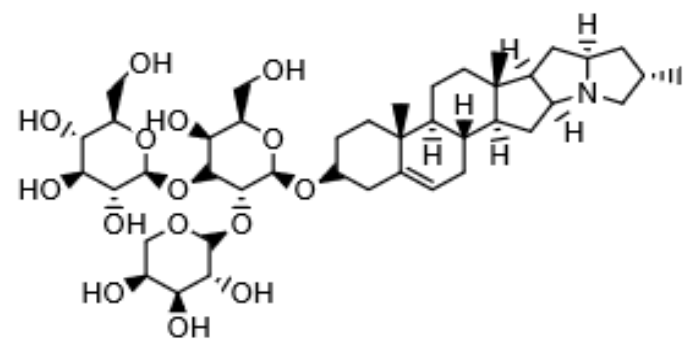

Gambar. Saponin

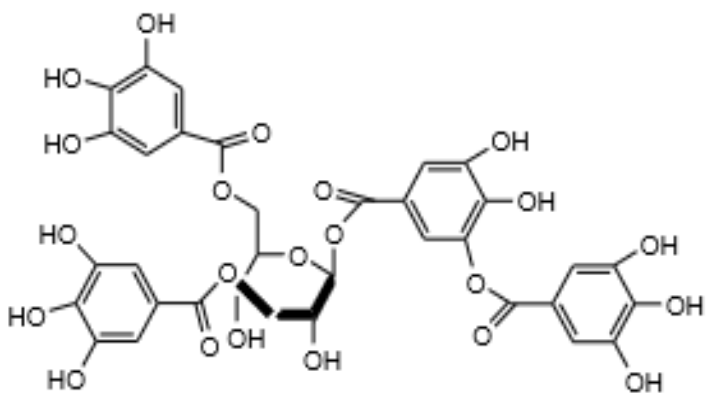

Gambar. Tannin

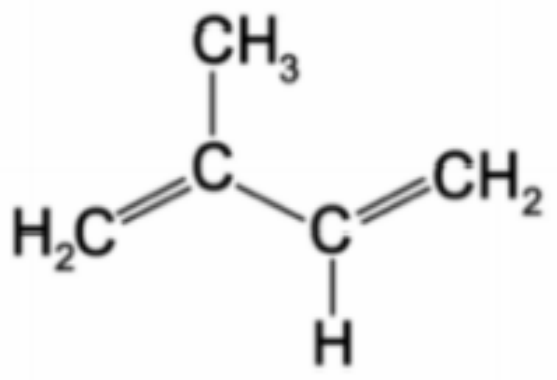

Gambar. Steroid 


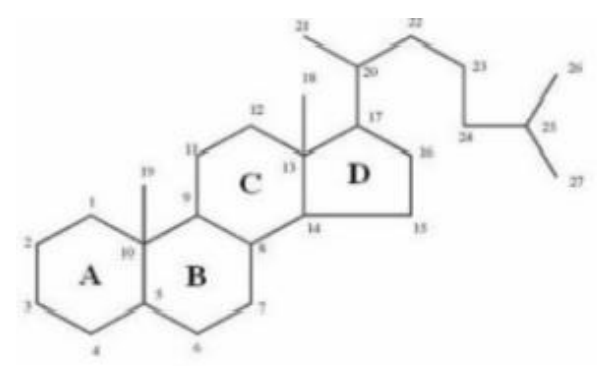

Gambar.Triterpenoid

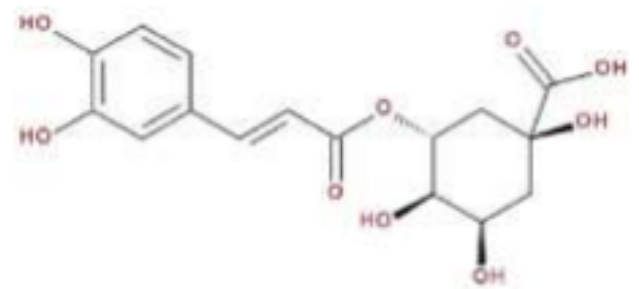

Gambar. Asam klorogenat<smiles>O=C(O)/C=C/c1ccc(O)c(O)c1</smiles>

Gambar. Asam kafeat

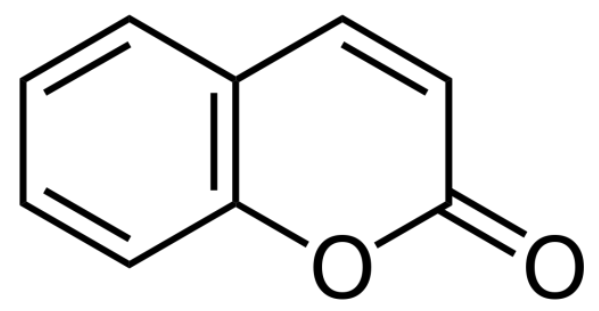

Gambar. Asam para kumarin 
<smiles>COc1cc(C(=O)O)ccc1O</smiles>

Gambar. Asam vanilat<smiles>O=C(O)c1ccccc1O</smiles>

Gambar. Asam hidroksibenzoat

Menurut penelitian, tanaman sambung nyawa memiliki aktivitas hipotensif, yang mampu menghambat efek tiramin dan efedrin, sehingga diduga bisa menghambat kerja obat simpatomimetik yang bisa menaikkan tekanan darah pada manusia. Dan aktivitas hipotensif inilah yang juga menghambat aktivitas enzim pengonversi angiostenin27[33-35]

\section{KESIMPULAN}

1. Ekstrak bisa dibuat dari rebusan daun sambung nyawa sebanyak 16 helai

2. Rebusan daun sambung nyawa dapat menurunkan tekanan darah tinggi atau hipertensi dalam 4 hari

3. Rebusan daun sambung nyawa dapat menurunkan tekanan darah tinggi karena mengandung flavonoid (glikosida kuersetin), tannin, saponin, steroid, triterpenoid, asam klorogenat, asam kafeat, asam para kumarin, dan asam para hidroksi benzoate 
4. Adanya aktivitas hipotensif yang mampu menghambat efek tiramin dan efedrin sehingga menurunkan hipertensi

\section{REFERENSI}

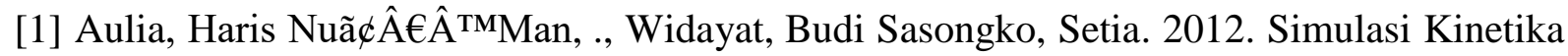
Reaksi Transesterifikasi Minyak Goreng Bekas Berbantukan Radiasi Ultrasonik. Prosiding Seminar Nasional Sains Dan Teknologi Fakultas Teknik. Vol 1, No 1

[2] Sanjaya, H. (2018) "Degradasi Metil Violet Menggunakan Katalis Zno-Tio2 Secara Fotosonolisis", Eksakta: Berkala Ilmiah Bidang Mipa, 19(1), Pp. 91-99. Doi: 10.24036/Eksakta/Vol19-Iss1/131.

[3] Widodo, Winarso D., Kurniawati, Ani, P, Edi Djauhari. 2008. Motode Adaptasi Tanaman Sambung Nyawa Terhadap Cahaya-Uv Untuk Meningkatkan Produksi Flavonoid. Jurnal Ilmu Pertanian Indonesia. Vol 13, No 3

[4] Darminto. 2009. Senyawa Alkoloid Dari Ekstrak Aseton Daun Sambung Nyawa Gynura Procumbens L. (Gpl). Bionature. Vol 10, No 1

[5] Kurnia, Erlin ( Sekolah Tinggi Ilmu Kesehatan-Kediri ), Suwardianto, Heru ( Stikes Rs. Baptis Kediri ). 2011 . Pengaruh Terapi Relaksasi Napas Dalam (Deep Breathing) Terhadap Perubahan Tekanan Darah Pada Penderita Hipertensi Di Puskesmas Kota Wilayah Selatan Kota Kediri. Jurnal Penelitian Stikes Kediri. Vol 4, No 1

[6] Rosyidah, Hesti ( Fakultas Kesehatan Masyarakat, Universitas Ahmad Dahlan, Yogyakarta ), Djannah, Sitti Nur ( Fakultas Kesehatan Masyarakat, Universitas Ahmad Dahlan, Yogyakarta ). 2010. Hubungan Antara Kadar Pb Dalam Darah Dengan Kejadian Hipertensi Pada Operator Spbu Di Kota Yogyakarta. Jurnal Kesehatan Masyarakat (Journal Of Public Health). Vol 4, No 2

[7] Dinata, M. And Soehardi, F. (2018) "Factor Analysis Of Physics Chemistry Waters That Affects Damage Safety Cliff On The Outskirts Of River Siak", Eksakta: Berkala Ilmiah Bidang Mipa, 19(2), Pp. 46-49. Doi: 10.24036/Eksakta/Vol19-Iss2/143.

[8] Putri, D., Fifendy, M. And Putri, M. (2018) "Diversitas Bakteri Endofit Pada Daun Muda Dan Tua Tumbuhan Andaleh (Morus Macroura Miq.)", Eksakta: Berkala Ilmiah Bidang Mipa, 19(1), Pp. 125-130. Doi: 10.24036/Eksakta/Vol19-Iss1/122. 
[9] Zainul, R. (2018, August 16). Effect of Temperature and Particle Motion against the ability of $\mathrm{ZnO}$ Semiconductor Photocatalyst in Humic Acid. https://doi.org/10.31227/osf.io/wnygb

[10] Zainul, R. (2018, August 16). Design and Modification of Copper Oxide Electrodes for Improving Conversion Coefficient Indoors Lights (PV-Cell) Photocells. https://doi.org/10.31227/osf.io/pgn84

[11] Suryelita, S., Etika, S. B. And Kurnia, N. S. (2017) "Isolasi Dan Karakterisasi Senyawa Steroid Dari Daun Cemara Natal (Cupressus Funebris Endl.)", Eksakta: Berkala Ilmiah Bidang Mipa, 18(01), Pp. 86-94. Doi: 10.24036/Eksakta/Vol18-Iss01/23.

[12] Mambang, D. Elysa Putri, Rosidah, -, Suryanto, Dwi. 2014. Aktivitas Antibakteri Ekstrak Tempe Terhadap Bakteri Bacillus Subtilis Dan Staphylococcus Aureus [Antibacterial Activity Of Tempe Extracts On Bacillus Subtilis And Staphylococcus Aureus]. Jurnal Teknologi Dan Industri Pangan. Vol 25, No 1

[13] Hadikusumo, Sutjipto A ( Jurusan Teknologi Hasil Hutan Fakultas Kehutanan Universitas Gadjah Mada ). 2007. Pengaruh Ekstrak Tembakau Terhadap Serangan Rayap Kayu Kering Cryptotermes Cynocephalus Light Pada Bambu Apus (Gigantochloa Apus Kurz). Jurnal Ilmu Kehutanan. Vol 1, No 2

[14] Sari, A. (2017) "Potensi Antioksidan Alami Pada Ekstrak Daun Jamblang (Syzigium Cumini (L.) Skeels)", Eksakta: Berkala Ilmiah Bidang Mipa, 18(02), Pp. 107-112. Doi: 10.24036/Eksakta/Vol18-Iss02/61.Kata

[15] Sumarmin, R. (2018) "Pengaruh Ekstrak Kulit Buah Manggis (Garcinia Mangostana L.) Terhadap Histologis Pankreas Mencit (Mus Musculus L. Swiss Webster) Yang Diinduksi Sukrosa", Eksakta: $\quad$ Berkala Ilmiah Bidang Mipa, 19(1), Pp. 100-112. Doi: 10.24036/Eksakta/Vol19-Iss1/123.

[16] Rizki Saputra, M. And Sumarmin, R. (2018) "Pengaruh Ekstrak Daun Sirih Merah (Piper Crocatum Ruiz \& Pav.) Terhadap Glukosa Darah Mencit (Mus Musculus L.) Jantan Yang Diinduksi Sukrosa", Eksakta: Berkala Ilmiah Bidang Mipa, 19(1), Pp. 43-55. Doi: 10.24036/Eksakta/Vol19-Iss1/124.

[17] Huda, N. (2017) "Pengaruh Ekstrak Sambiloto (Andrographis Paniculata Nees.) Terhadap Siklus Estrus Mencit (Mus Musculus L. Swiss Webster)”, Eksakta: Berkala Ilmiah Bidang Mipa, 18(02), Pp. 69-76. Doi: 10.24036/Eksakta/Vol18-Iss02/55.

[18] Iryani, I., Iswendi, I. And Katrina, I. T. (2017) "Uji Aktivitas Anti Diabetes Mellitus Senyawa Metabolit Sekunder Fraksi Air Dari Beras Ketan Hitam ( Oryza Satival. Var Glutinosa) Pada Mencit Putih", Eksakta: Berkala Ilmiah Bidang Mipa, 18(01), Pp. 54-60. Doi: 10.24036/Eksakta/Vol18-Iss01/17. 
[19] Zainul, R., Alif, A., Aziz, H., Arief, S., Dradjad, S., \& Munaf, E. (2015). Design Of Photovoltaic Cell With Copper Oxide Electrode By Using Indoor Lights. Research Journal Of Pharmaceutical Biological And Chemical Sciences, 6(4), 353-361.

[20] Horiza, H. (2018) "The Influence Of The Use Of Activated Carbon Fibres Of The Cane Against The Drop In Salinity In The Well Dig In Rt 003 Rw 006 Village Cape Town Unggat Tanjungpinang Year 2017', Eksakta: Berkala Ilmiah Bidang Mipa, 19(1), Pp. 1-6. Doi: 10.24036/Eksakta/Vol19-Iss1/97.

[21] Hamidy, M Yulis, Malik, Zulkifli, Machyar, Ryan Mutiara. 2009. Gambaran Histopatologi Kerusakan Hati Mencit Yang Diproteksi Dengan Air Rebusan Daun Sirih \{Piper Betle Linn). Jik ( Jurnal Ilmu Kedokteran ). Vol 3, No 1.

[22] Anhar, A., Sumarmin, R., \& Zainul, R. (2016). Measurement Of Glycemic Index Of West Sumatera Local Rice Genotypes For Healthy Food Selection. Journal Of Chemical And Pharmaceutical Research, 8(8), 1035-1040.

[23] Ruswandi, R. (2018) "Determination Of Fructose Content Resulted By Inulin Hydrolysis With Dns As Oxidizer”, Eksakta: Berkala Ilmiah Bidang Mipa, 19(1), Pp. 14-23. Doi: 10.24036/Eksakta/Vol19-Iss1/102.

[24] Yohana C. Sulistyaningsih, Dorly Dorly, Hilda Akmal. 1994. Studi Anatomi Daun Saccharum Spp. Sebagai Induk Dalam Pemuliaan Tebu. Hayati Journal Of Biosciences. Vol 1 , No 2

[25] Zainul, R. (2018, August 16). Determination of the half-life and the quantum yield of $\mathrm{ZnO}$ semiconductor photocatalyst in humic acid. https://doi.org/10.31227/osf.io/e8a9x

[26] Effendi, M. Supli. 2002. Kinetika Fermentasi Asam Asetat (Vinegar) Oleh Bakteri Acetobacter Aceti B 127 Dari Etanol Hasil Fermentasi Limbah Cair Pulp Kakao [Kinetics Of Acetic Acid (Vinegar) Fermentation By Acetobacter Aceti B127 From Ethanol Produced By Fermentation Of Liqu. Jurnal Teknologi Dan Industri Pangan. Vol 13, No 2

[27] Chatri, M., Mansyurdin, M., Bakhtiar, A. And Adnadi, P. (2017) "Perbandingan Komponen Minyak Atsiri Antara Daun Muda Dan Daun Dewasa Pada Hyptis Suaveolens (L.)Poit", Eksakta: $\quad$ Berkala Ilmiah Bidang $\quad$ Mipa, $\quad$ 18(02), $\quad$ Pp. 1-12. Doi: 10.24036/Eksakta/Vol18-Iss02/41.

[28] Iskandar, I., Horiza, H. And Fauzi, N. (2017) "Efektivitas Bubuk Biji Pepaya (Carica Papaya Linnaeaus) Sebagai Larvasida Alami Terhadap Kematian Larva Aedes Aegypty Tahun 2015", Eksakta: Berkala Ilmiah Bidang Mipa, 18(01), Pp. 12-18. Doi: 10.24036/Eksakta/Vol18-Iss01/12. 
[29] Setianto, S. (2017) "Analisa Kuantitatif Campuran Senyawa Oksida Sebagai Dasar Identifikasi Kandungan Bahan Sumber Daya Alam Studi Kasus : Kandungan Mineral Pada Pasir Besi Di Pesisir Pantai Selatan, Jawa Barat", Eksakta: Berkala Ilmiah Bidang Mipa, 18(02), Pp. 173-177. Doi: 10.24036/Eksakta/Vol18-Iss02/74.S

[30] Anwar, M., Munaf, E., Kosela, S., Wibowo, W., \& Zainul, R. (2015). Study Of Pb (Ii) Biosorption From Aqueous Solution Using Immobilized Spirogyra Subsalsa Biomass. Journal Of Chemical And Pharmaceutical Research, 7(11), 715-722.

[31] Zainul, R., Alif, A., Aziz, H., \& Arief, S. (2015). Disain Geometri Reaktor Fotosel Cahaya Ruang. Jurnal Riset Kimia, 8(2), 131.

[32] Syafei, N., Hidayat, D., Emilliano, E. And Men, L. (2018) "Analysis Cracking Corrosion On Carbon Steel Pipes Api 51-X65 In Solution 7700 Ml Aquades, 250 Ml Acetic Acid And 50 Ml Ammonia With Gas Co2 And H2s In Saturation Condition", Eksakta: Berkala Ilmiah Bidang Mipa, 19(2), Pp. 21-31. Doi: 10.24036/Eksakta/Vol19-Iss2/138.

[33] Rahadian Zainul, Admin Alif, Hermansyah Aziz, Syukri Arief, Syukri And Arief Yasthopi. 2015. Photoelectrosplitting Water For Hydrogen Production Using Illumination Of Indoor Lights. Journal Of Chemical And Pharmaceutical Research. 7(11):57-67.

[34] Zainul, R. (2018, August 16). Design and Modification of Copper Oxide Electrodes for Improving Conversion Coefficient Indoors Lights (PV-Cell) Photocells. https://doi.org/10.31227/osf.io/pgn84

[35] Febriani, S. S., Yolanda, T., Arianti, V. A., \& Zainul, R. (2018, October 12). A Review Solid Stated : Principles and Methode. https://doi.org/10.31227/osf.io/7us4x 
